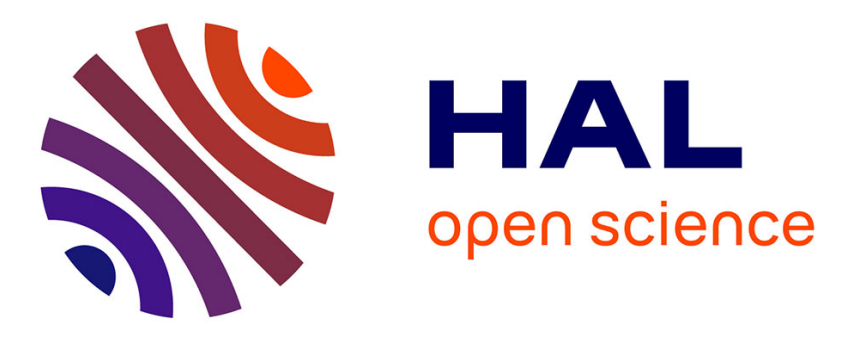

\title{
Effects of the Logistics in the Volume of Soybean by Export Corridor of Mato Grosso
}

Rodrigo Carlo Toloi, João Reis, Oduvaldo Vendrametto, Sivanilza Teixeira Machado, Valdir Morales

\section{- To cite this version:}

Rodrigo Carlo Toloi, João Reis, Oduvaldo Vendrametto, Sivanilza Teixeira Machado, Valdir Morales. Effects of the Logistics in the Volume of Soybean by Export Corridor of Mato Grosso. IFIP International Conference on Advances in Production Management Systems (APMS), Sep 2016, Iguassu Falls, Brazil. pp.571-578, 10.1007/978-3-319-51133-7_68 . hal-01615803

\section{HAL Id: hal-01615803 \\ https://hal.inria.fr/hal-01615803}

Submitted on 12 Oct 2017

HAL is a multi-disciplinary open access archive for the deposit and dissemination of scientific research documents, whether they are published or not. The documents may come from teaching and research institutions in France or abroad, or from public or private research centers.
L'archive ouverte pluridisciplinaire HAL, est destinée au dépôt et à la diffusion de documents scientifiques de niveau recherche, publiés ou non, émanant des établissements d'enseignement et de recherche français ou étrangers, des laboratoires publics ou privés.

\section{(c)(1)}

Distributed under a Creative Commons Attribution| 4.0 International License 


\title{
Effects of the Logistics in the Volume of Soybean by Export Corridor of Mato Grosso
}

\author{
Rodrigo Carlo Toloi ${ }^{1,2}$, João Gilberto Mendes dos Reis ${ }^{1}$, Oduvaldo \\ Vendrametto $^{1}$, and Sivanilza Teixeira Machado ${ }^{1,3}$ and Valdir Morales ${ }^{1}$ \\ 1 Paulista University, São Paulo, Brazil \\ 2 Federal Institute of Mato Grosso Campus Rondonópolis, Rondonópolis, Brazil \\ 3 Federal Institute of São Paulo Campus Suzano, Suzano, Brazil \\ rodrigo.toloi@roo.ifmt.edu.br
}

\begin{abstract}
Brazil is one of the biggest producer and exporter of soybean. Its production is basically divided among six main players which Mato Grosso alone responds for $29,3 \%$ of total production of the country. The aim of this paper is to investigate the relation between logistics factors and the volume of soybean transported by corridors of exportation. To this end, we develop a multi-linear regression model and tested using data of Mato Grosso state. The results show that low transportation costs per ton, port capacity and increase soybean volume in the corridor of exportation.
\end{abstract}

Keywords: Transportation Cost, Soybean Exportation, Multi-linear Regression Model, SPSS, Brazil.

\section{Introduction}

Brazil is responsible for approximately $40 \%$ of the world soybean production [1]. Its production is divided into six main states: Mato Grosso (29,3\%), Paraná (18\%), Rio Grande do Sul (15,4\%), Goiás (9,2), Mato Grosso do Sul $(7,4 \%)$, and Bahia (4,5\%). Mato Grosso is located in the midwest region and it is responsible itself for 27,87 millions of tons of soybean grain [2]. However, despite the excellent productivity of the State and the huge market for Brazil's soybean, the logistics can be considered a challenge for whole supply chain due to their costs. [3].

The country has demonstrated logistical shortcomings in its handling of soybean trade, marketing fragility to ensure the efficiency of this export system [4]. Brazil's infrastructure is creaking under the country's rapid economic growth, presenting difficulties for importers and exporters [5]. Transport soybeans overland in Brazil may be up to three times more expensive than in the United States $[5,6]$.

Soybean is a commodity and has its price established internationally, therefore, the producers don't have its price control. Thus, to become competitive, the soybean supply chains needs to be capable of manage effectively the move costs [7]. 
In this context, the aim of this paper is to investigate how logistics factors such as time travel, transportation costs, and port capacity can influence in the volume of soybean exportations by route. To this end, a multi-linear regression was performed using exportation data and costs of the Mato Grosso state.

The paper is organized as follows. After this Introduction, the section two shows the methodology, section three the results, section four the discussion, and finally section five the main conclusions of the work.

\section{Methodology}

To understand the influence of the logistics in soybean exportations, we choose Mato Grosso state in Brazil for three reasons: (i) Brazil is top three in production and exportation of soybean; (ii) Mato Grosso state is the major producer and exporter of the country; (iii) The large availability of data to conduct the study.

Mato Grosso export soybean for the follow ports: Aracaju (Sergipe), Bacarena (Pará), Ilhéus (Bahia), Imbituba (Santa Catarina), Manaus(Amazon), Paranaguá (Paraná), Rio Grande (Rio Grande do Sul), Salvador (Bahia), Santarém (Pará), Santos (São Paulo), São Francisco do Sul (Santa Catarina), São Luiz(Maranhão), and Vitória (Espirito Santo). In a previous study, we could analyse the volume to route and use to operational research to propose improvements in soybean exportation corridors of Mato Grosso state [8]. Now, we are trying to comprehend why these current routes are used to move Mato Grosso soybean to exportation.

In this analysis, we opted to use logistics factors related to soybean movement in the transport corridors of Mato Grosso. Therefore, we choose transportation costs per ton, transportation costs by total volume, port capacity to move soybean, and time travel.

This is an exploratory study and by now we used some variables with data available. However, we believe that does not affect the final conclusions because is a preliminary study and other kinds of variables will be used in the future such as modal of transportations available, storage systems, road quality and so on.

To test the hypothesis that the logistics have effect in the volume of soybean per route in Mato Grosso, we used the multi-linear regression analysis [9]. The model was created considering the variables showed in the Eq.(1).

$$
X_{i j t}=\alpha+\beta_{1} T T_{i j}+\beta_{2} C U T_{i j}+\beta_{3} C A P_{j}+\beta_{4} C T T_{i j t}
$$

Where,

- $X_{i j t}$ is the dependent variable that represents volume of soybean transported between Mato Grosso (i) and a specific port (j) per year (t) between 2005 and 2015;

$-T T_{i j}$ is the independent variable that corresponds to time travel between Mato Grosso (i) and specific Brazilian port among the indicate above (j);

- $C U T_{i j}$ is the independent variable that corresponds to cost of transport per ton in Brazilian monetary; 
- $C A P_{j}$ is the independent variable that corresponds to port capacity;

- $C T T_{i j t}$ is the independent variable that corresponds to the total cost of transportation to move soybean grain between Mato Grosso (i) and a specific port $(\mathrm{j})$ in a year $(\mathrm{t})$.

\subsection{Sample}

The sample considered in this study were 129 movements of soybean grains between Mato Grosso state and its main ports of exportation during the period from 2005 to 2015.

In our study, we exclude 57 moves because of volume was under 5.000 tons. However, the other 72 transactions corresponding to $99,98 \%$ of soybean volume. The source of data can be seen in Table 1

Table 1. Data Source

\begin{tabular}{|c|c|}
\hline Data & Source \\
\hline Volume of transportation between Mato & (Brazilian \\
\hline Grosso state and Brazilian ports during & Information System of trades) \\
\hline $2005-2015$ period (Xijt) & http://aliceweb.desenvolvimento.gov.br/ \\
\hline $\begin{array}{l}\text { Time Travel between Mato Grosso and } \\
\text { Brazilian ports (TT) }\end{array}$ & $\begin{array}{l}\text { Mapeia (the site for calculation of } \\
\text { distances and time spent on routes) } \\
\text { http://www.mapeia.com.br }\end{array}$ \\
\hline $\begin{array}{l}\text { Unit Cost Transportation in Brazilian reais } \\
\text { per ton between Mato Grosso state and } \\
\text { Brazilian ports (CUT) }\end{array}$ & \\
\hline $\begin{array}{l}\text { Port capacity in ton for soybean grain } \\
\text { (CAPj) }\end{array}$ & \begin{tabular}{lcr} 
Aliceweb & (Brazilian & \multicolumn{2}{c}{ Government } \\
Information & System of trades) \\
http://aliceweb.desenvolvimento.gov.br/
\end{tabular} \\
\hline Cost total of trans & \\
\hline
\end{tabular}

\subsection{Regression Analysis}

The regression analysis it is a statistic technique to model and investigate the relation between some variables. One of the regression analysis is to establish a relation that allows predicting one or more variables in terms of others. The study data were processed using the IBM ${ }^{\circledR}$ SPSS ${ }^{\circledR}$ version 22 Software. The SPSS - Statistical Package for the Social Science is a statistic and data software that analyze and offer advanced techniques easily and intuitively to help and get a better efficiency minimizing the risks concerned to statistic and handling from the data.

\section{Results}

In order to verify the relation between the variables studied we start summarizing the descriptive statistics (Table 2). 
Table 2. Descriptive statistics.

\begin{tabular}{lrrrrr}
\hline $\mathbf{V}$ & N Minimum & Maximum & Average & Std. Dev. \\
\hline TT & 72 & $26.01 \mathrm{~h}$ & $34.03 \mathrm{~h}$ & $30.02 \mathrm{~h}$ & $2.67 \mathrm{~h}$ \\
CUT 72 & $\$ 61.58$ ton & $\$ 77.03$ ton & $\$ 69.30$ ton & $\$ 5.15$ ton \\
X & 72 & 9,681 ton & $7,199,622$ ton $3,599,815$ ton $2,399,871$ ton \\
CAP 72 & 9,754 ton & 384,583 ton & 197,168 ton & 124,943 ton \\
CTT 72 & $\$ 0.74^{*}$ & $\$ 443.32^{*}$ & $\$ 222.03^{*}$ & $\$ 147.53^{*}$ \\
\hline
\end{tabular}

*million dollars

In relation to the transport time (TT), they have spent an average to the transport of soybean, 30,02 h [7]. The transport cost per ton (CUT), was defined a medium amount of US\$ 69.30 per ton. As the transport time as well as the transport costs per ton can be considered high when compared with the main Brazilian competitor which is the United States that has a cost over $43 \%$ less on internal transport and three days less in travel time [6] and [10].

The port capacity showed a striking difference between the minimum values (9.754 ton) and a maximum of (384.583 ton.). It may indicate that there is filler concentration in some ports. The port capacity (CAP) was 197.168 ton. The variable cost total transport (CTT) it has a standard deviation cost of US\$ 147.53 million with a media value of US\$ 222.03 million, that confirms that the value movement transport in different volumes between ports. Santos and Paranguá ports are responsible together for to transport 45,3\% of Brazil's soybean exportation and $66,22 \%$ of Mato Grosso soybean [11].

The variables were inserted in the multi-linear regression model using the Stepwise method, to verify which variables could be considered important. The importance of all variables to the Study Model it is resumed on Table 3.

Table 3. Model Result

\begin{tabular}{lrrrc}
\hline \multicolumn{1}{c}{ Model } & Estimate Std Error & \multicolumn{1}{c}{$\boldsymbol{t}$} & Sig. \\
\hline (Constant) & $708,302.90$ & $135,509.440$ & 5.23 & 0,000 \\
CTT & 0.004 & 0.000 & 88.71 & 0.000 \\
CTU (US\$/metric ton) & 832.30 & 139.20 & -5.98 & 0.000 \\
CAP & 0.468 & 0.170 & 2.83 & 0.006 \\
\hline
\end{tabular}

a. Variable Dependent: Volume (metric ton)

Observing the significance, it is shown that the volume of soybean transported per route can be explained by the behavior of the variables, Transport Cost per ton and Port Capacity $(p<0,05)$. We conclude that the initial model can be adjusted Eq.(2).

$$
X_{i j t}=\alpha-\beta_{1} C U T_{i j}+\beta_{2} C A P_{j}+\beta_{3} C T T_{i j t}
$$


That replaces the coefficient values has the following relation (Eq. 3).

$$
X_{i j t}=708,302.9-832.30 C U T+0.468 C A P+0.004 C T T
$$

The independent variables CAP and CTT show a positive coefficient, in other words, they influence positively the transport volume. When the capacity of port increase, it can provokes effect in load flow in the route. However, the CTT presented low influence (0.004), therefore, is not possible conclude its effect in corridor use. Note that has a higher difference between volume per route and this may affect the result (Table 2).

The most important independent variable in our study was CUT. This variable confirms the operational practice from routes with major load volume, where the low price of transportation per ton increase volume (negative signal).

However, it is important to realize that the inverse may occur, where the high volume reduce the freight prices, but this situation needs to confirm statistically in further studies.

The validation of this model and their results can be estimated based on values measure $R$, that can be visualized on Table 4 .

Table 4. Model Summary

\begin{tabular}{llllll}
\hline Model & $\mathbf{R}$ & \multicolumn{4}{c}{ R Square Adj. R Square Std. Error Durbin-Watson } \\
\hline 1 & $0,999 \mathrm{a}$ & 0,999 & 0,999 & $65.939,23$ & 0,448 \\
\hline \multicolumn{2}{l}{ a.Predictors: (Constant), Total Cost of Transportation, Transport Unit } \\
Cost (US/ton), Port Capacity. \\
b.Dependent Variable: Volume (ton).
\end{tabular}

Note that $\mathrm{R}$ represented the positive value 0,999 , thus, the adjustment got close to 1 , therefore, the difference is justify throug the estimated mistake. In this dependente model the transport and all the variables, independent it was the transport total cost, unitary transport cost, unitary total transport cost, unitary total transport cost from the Port. The proposed $R$ model explains the dependent variables volume (ton) around 99,9\% from all the cases as shown the value $R^{2}(0,999)$. Lastly, to observe if the equation is right (2), Figure 1 describes the relation between independent and dependente as the linear multilinear regression model.

Note that $\mathrm{R}$ represented the positive value 0,999 . The proposed $R$ model explains the dependent variables volume (ton) around $99,9 \%$ from all the cases as shown the value $R^{2}(0,999)$. Lastly, to observe that equation 2 can be confirmed (2).

Figure 1 describes the relation between independent and dependent in the multi-linear regression model. 


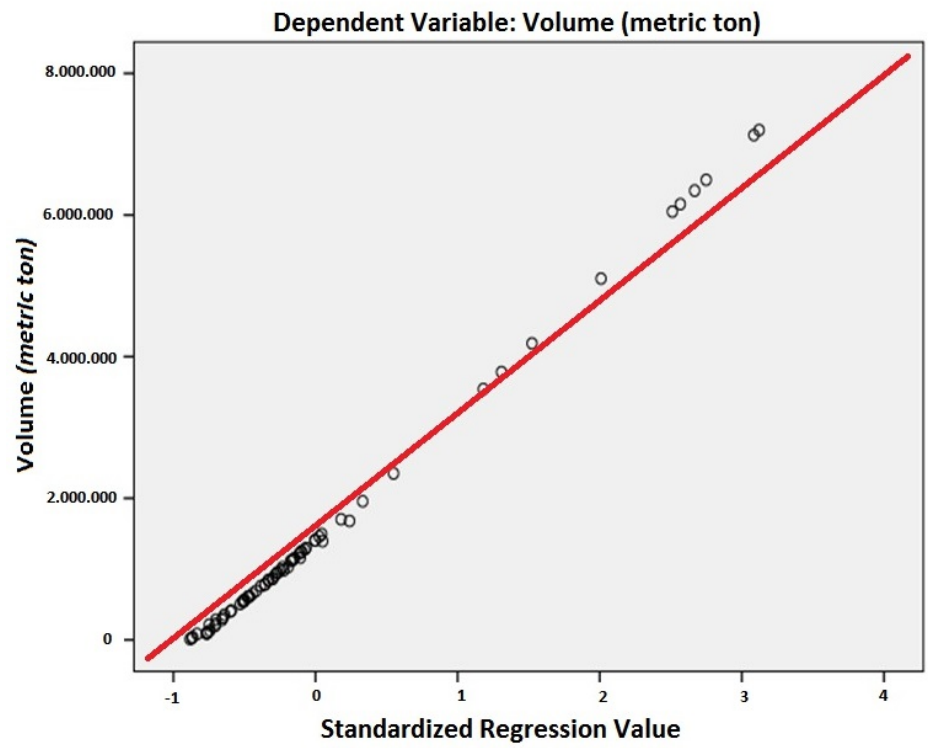

Fig. 1. Scatter Chart

\section{Discussion}

Considering these results, some discussion can be made to understand the Brazilian reality:

- Logistical Deficit: Brazil needs improve logistical infrastructure such as storage, rivers infrastructure, modal with higher capacity of transportation. The Agricultural Department of United States suggests the logistical deficit in Brazil is the obstacle to the development of Brazilian agroindustrial sector [12].

- Transporte Cost: The soybean transport costs can achieve around 25\% from the product value [12]. The obstacle is the excess of roadways with less load capacity and major costs of transportation per ton versus kilometers. The roadway model still shows a big amount of obstacles that goes such the low capacity and fleet density, bad conservation in high levels of accidents frequently lost os grains during transport [12], [13]. The Transport Cost in the United States is average 30 dollars while in Brazil is about 70, mainly Because of use of railroad and Waterway transports [10].

- Port Capacity: Brazil has only two ports with a major capacity to the grains flow. They are Paranaguá and Santos. These two ports have main routes to flow the major quantity of freight which makes have been used intensively. It raises a bottleneck in loading and unloading and retention value. Thus, can be defined as bottlenecks and less availability to storage 
[14]. Besides a great traffic such as on the ground and in the sea: truck rows that stay in ports to upload and the time that the big ships. The results of this problem are long rows, delays, shipments, and losses. The demand is about $30 \%$ major than the offer. The greatest demand should the rent ships increase, which increase the freight costs [15]. Lastly, The Brazilian Port system floodgate two realities: the private terminal and the public dock. The private terminal has gains of productiveness, consequently in a better management, which made possible make equipment modernization and movimentation process from the loads. The situation on the public dock is really the opposite with obsolecence and bad use of facilities and equipment, which commits the competitiveness in the soybean chain [16].

\section{Conclusions}

The soybean is responsible for a large movement and foreign exchange for the country. However, as soybean is low value added product is necessary to optimize process and reduce costs. Considering that the growth of the soybean culture is migrating into the country is essential improved logistics infrastructure, given that the distance between the growers and ports can exceed easily two thousand kilometers.

This study used a multi-linear regression model to analyze the behavior soybean volume in relation to logistics variables. We could confirm that low transportation costs and port capacity can increase of soybean volume by route and vice versa.

\section{References}

1. United States Department of Agriculture: Oilseed: World Market and Trade. Tech. rep., United States Department of Agriculture, EUA (2016)

2. Ministry of Agriculture, Livestock and Food Supply: Projections of Agribusiness: Brazil 2014/15 to 2024/25: Long Term Projections. MAPA, Brasília (2015)

3. Bustos, P., Garber, G., Ponticelli, J.: Capital Allocation Across Sectors: Evidence from Boom in Agriculture. Working Paper Series, Banco Central do Brasil, Brasília (2016)

4. Reis, S.A., Leal, J.E.: A Deterministic Mathematical Model to Support Temporal and Spatial Decisions of the Soybean Supply Chain. Journal of Transport Geography 43, 48-58 (2015)

5. Pearson, S.: Infrastructure: Poor Logistics Present a Problem for Partnership. Financial Times (2011)

6. Salin, D.: Soybean transportation guide: Brazil 2014. FAS/USDA (2015)

7. Gonçalves, D.N.S., Gonçalves, C.d.M., Assis, T.F.d., Silva, M.A.d.: Analysis of the Difference Between the Euclidean Distance and the Actual Road Distance in Brazil. Transportation Research Procedia 3, 876 - 885 (2014)

8. Toloi, R.C., Reis, J., Vendrametto, O., Machado, S., Rodrigues, E.: How to Improve the Logistics Issues During Crop Soybean in Mato Grosso State Brazil? In: ILS 2016: Building a Resilient Future. vol. 1, pp. 1-7. ILS, Bordeaux (2016) 
9. Asadi, S., Amiri, S.S., Mottahedi, M.: On the Development of Multi-Linear Regression Analysis to Assess Energy Consumption in the Early Stages of Building Design. Energy and Buildings 85, 246 - 255 (2014)

10. Reis, J.G.M., Vendrametto, O., Naas, I.d.A., Costabile, L.T., Machado, S.T.: Avaliação das Estratégias de Comercialização do Milho em MS Aplicando o Analytic Hierarchy Process (AHP). Revista Economia e Sociologia Rural 54(01), 131146 (2016)

11. Ministério Desenvolvimento Indústria e Comércio: (2016), http://aliceweb. mdic.gov.br//consulta-ncm/consultar

12. United States Department of Agriculture: World Agricultural Supply and Demand Estimates, vol. 550. United States Department of Agriculture, Washington (2016)

13. Kussano, M.R., Batalha, M.O.: Custos Logísticos Agroindustriais: Avaliação do Escoamento da Soja em Grão do Mato Grosso para o Mercado Externo. Gestão \& Produção 19, 619 - 632 (2012)

14. Instituto Mato-grossense de Economia Agropecuária: Entendendo o Mercado da Soja. Tech. rep., Instituto Mato-grossense de Economia Agropecuária, Cuiabá/MT (2015)

15. Pontes, H.L.J., Carmo, B.B.T., Porto, A.J.V.: Problemas Logísticos na Exportação Brasileira da Soja em Grão. Revista Eletrônica Sistemas \& Gestão 4(2), 155-181 (2009)

16. Filardo, M.L.R., Ilario, A.A., Silva, G.D.d., Carvalho, M.A.d.: A Logística da Exportação de Soja do Estado de Mato Grosso para o Porto de Santos 3(3), 35-52 (2005) 